\title{
Interpretation of the results of mechanical rock properties testing with respect to mining methods
}

\author{
Eukasz BOEOZ ${ }^{*}$
}

Authors' affiliations and addresses: ${ }^{1}$ AGH University of Science and Technology, Department of Machinery Engineering and Transport, A. Mickiewicza Av. 30, 30-059 Krakow, Poland

e-mail: e-mail boloz@agh.edu.pl

*Correspondence:

Łukasz Bołoz, AGH University of Science and Technology, Department of Machinery Engineering and Transport, A. Mickiewicza Av. 30, 30-059 Krakow, Poland

e-mail: e-mail boloz@agh.edu.pl

Funding information:

AGH University of Science and Technology, Faculty of Mechanical Engineering and Robotics, 16.16.130.942

How to cite this article:

Bołoz, L. (2020). Interpretation of the results of mechanical rock properties testing with respect to mining methods. Acta Montanistica Slovaca, Volume 25 (1), 81-93

DOI: https://doi.org/10.46544/AMS.v25i1.8

\begin{abstract}
The article is concerned with the influence of cutting direction on rock cutting resistance, which is a frequently neglected issue. Investigations into the mechanical properties of the unmined rock are carried out at the stage of works involving deposit identification or mining method selection. The most frequently performed tests include uniaxial compressive strength and, sometimes, mineability of the unmined rock. The results of these tests are strongly correlated with the direction in which they have been carried out. Additionally, depending on the method of mining (cutting, planning, drilling) and the site of sampling (sidewall, face), the direction of cutting is usually inconsistent with the direction of testing. In the article, the author has drawn attention to the commonly applied directions of cutting and presented recommendations on the direction of testing to be followed in underground mining plants in order to properly determine the unmined rock properties. The results of the author's research into a hard coal mine, rock salt and sandstones, shales and dolomites, conducted in three perpendicular directions have also been quoted. Furthermore, the subject literature in this field has been reviewed, and selected investigations presented. The research results confirm that depending on the cutting direction, there may be considerable, even fivefold differences in the value of mechanical properties. Knowing the planned cutting direction and the direction of testing is a necessary condition for interpreting the results in a proper way, choosing a suitable mining technique, the type of tools and process parameters, as well as achieving the projected efficiency and energy consumption.
\end{abstract}

\section{Keywords}

mechanical properties of rocks, selection of a mining method, rock anisotropy, mechanical cutting of rocks, cutting, planning, drilling

(C) 2020 by the authors. Submitted for possible open access publication under the terms and conditions of the Creative Commons Attribution (CC BY) license (http://creativecommons.org/licenses/by/4.0/). 


\section{Introduction}

The exploitation of useful minerals is accompanied by gangue mining. Both useful minerals and gangue can be mined by various methods. Useful minerals in underground mines most frequently include hard coal, ores of metals, in particular copper, iron, zinc and lead; rock and potassium salts; sulphur and others. Opencast mining also involves the mining of brown coal or building rock, such as marble or granite.

The simplest method, which is still applied on a small scale, is manual mining, for example with picks or hammers. However, the vast majority of mining processes are mechanized. The techniques used in underground mining machines are usually based on cutting, planning and drilling. Salts, as well as hard mineable and abrasive rocks, such as ores, are frequently mined with explosives. The winning efficiency, and, in consequence, the efficiency of exploitation, is mostly influenced by the mechanical properties of unmined rock, which are determined by a number of parameters. A parameter easy to determine and use is uniaxial compressive strength $R_{c}$, expressed in megapascals. This parameter does not describe the rock in a sufficient way, however. Knowing merely the value of compressive strength does not allow mining resistance to be determined (Biały, 2013), (Biały, 2014) (Biały and Fries, 2019). Rocks characterized by high compressive strength $R_{c}$ can be easily mineable and vice versa; despite a relatively low value of $R_{c}$, the rock can be hard mineable. For this reason, rock mineability is frequently specified by determining mineability index $A$, which is expressed in newtons per centimetre, and by breakout angle $\psi$, expressed in degrees. All the three values enable selecting a method of winning, appropriate tools and head, as well as estimating the resistance of mining (Bołoz et al., 2018). It is of paramount importance, especially in the case of the most popular and efficient machines, i.e., mechanized longwall systems and roadheaders.

Compressive strength and rock mineability are usually determined in laboratory conditions. A sample subjected to tests can have a different direction in relation to that in the deposit. Investigations into rock properties conducted in laboratory conditions concern only one direction. Typical winning machines used in underground mining carry out the rock cutting process in a different way. An analysis of typical machines has revealed that mining resistance depends on various directions, which are most frequently inconsistent with the direction for which the mechanical properties of unmined rock have been determined. On the other hand, the results of mechanical properties tests conducted in three perpendicular directions indicate considerable differentiation in the obtained results, that is, rock anisotropy. Generally, anisotropy points to the influence of direction on rock properties. However, investigations conducted in three perpendicular directions are, in fact, research into orthotropy, which is a special case of anisotropy. For the analyzed problem, there is no need to determine directions in which properties are the most differentiated, as the directions are imposed by the directions of cutting and location in the deposit.

The direction for which mechanical rock properties will be determined should, therefore, be carefully determined while taking into account the exploitation method planned. Determination of the direction is vitally important, especially if there is a possibility of carrying out tests only in one, selected direction.

The article has been based on the results of laboratory research on rock properties obtained in numerous works in this field. Various rocks, such as brown coal, rock salt, sandstone, dolomite and shale, have been subjected to tests. The collected results have been subjected to analysis, and the observed correlations have been presented. Recommendations for selecting the direction of investigations into rock properties and their interpretation in relation to the specified mining method have been based on the theory of cutting as well as the experiences and analysis of cutting processes carried out with various machines.

\section{Literature review}

Information on anisotropy appears in publications devoted to mechanical properties of rocks, from the point of view of mining and geology as well as mining mechanization. It is a well-known and obvious subject. Below have been quoted selected research results and relevant conclusions.

The investigations quoted in the literature most frequently concern properties of particular rocks or the influence of various parameters (sample length/diameter ratio, humidity, weathering, etc.) on compressive strength (Agustawijaya, 2007). As early as several dozen years ago, it was found that rock anisotropy could cause differences in mechanical properties in 1:5 ratio (Muller and Pacher, 1965). The authors of those investigations emphasized that anisotropy was a typical phenomenon. The chart developed by the authors, which has been presented in Fig. 1a, concerns the case of stratified rocks.

In one of the publications (Nasseria et al., 2003), detailed results of research on a few types of shale for a full range of angles have been presented. The results of uniaxial compressive strength have revealed threefold differences in values, depending on the direction of shale layers during testing. Similar results were obtained for other materials, including shale (Fig. 1b), (Shuxin, 1992).

Sometimes the method of mining is chosen only on the basis of information on uniaxial compressive strength obtained as a result of investigations into core barrels at the stage of prospecting works. In such a case, 
the only available data is the value of $R_{c}$ in one direction (fig. 1c). In some investigations, attention has been drawn to differences in uniaxial compressive strength, reaching up to $50 \%$, depending on the core barrel inclination angle (Majcherczyk and Niedbalski, 2004).

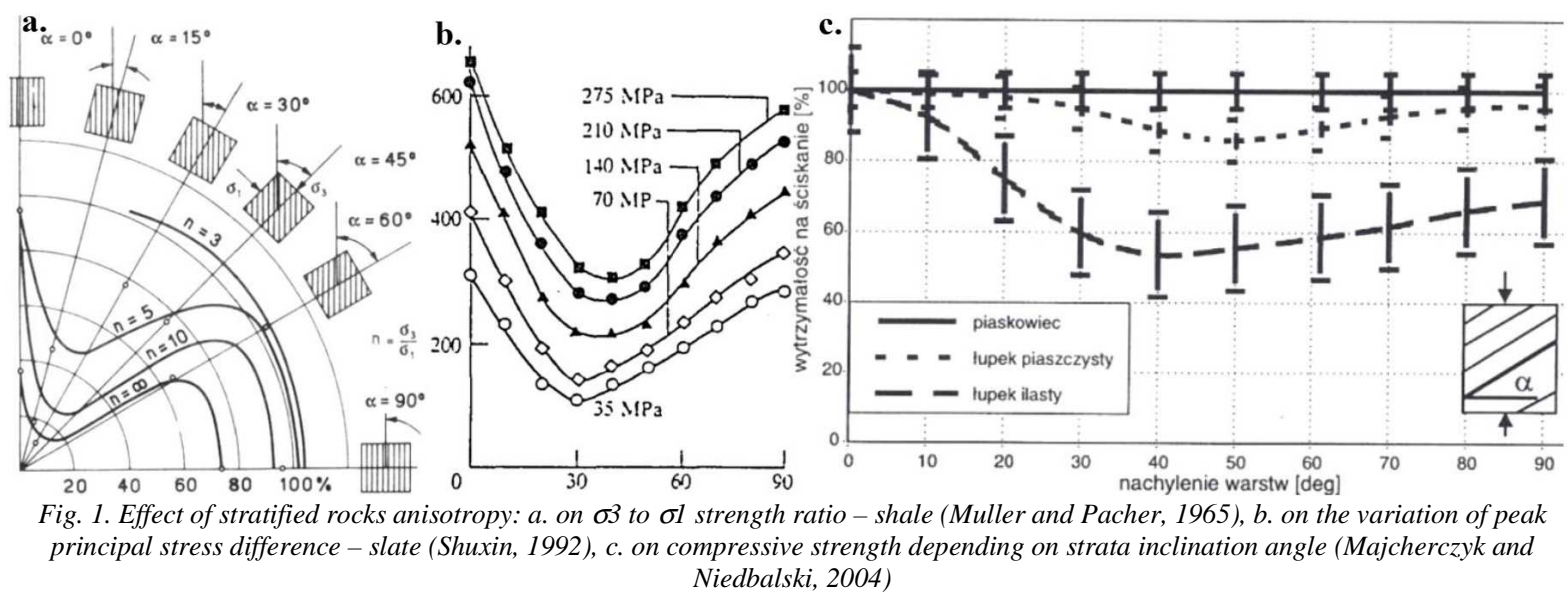

In numerous works concerning the mechanical properties of rocks that have been published in recent years, attention has been drawn to anisotropy (Małkowski, 2015), (Ozcelik and Yilmazkaya, 2011), (Özbek et al., 2018), (Dinc et al., 2011). Apart from research into typical rocks mined in underground plants, it is worth quoting investigations into rocks from open-pit mines. Rocks subjected to testing included limestone, dolomite, claystone, marble (Hoek, 1980). There are reports in the subject literature indicating that the way rock is deposited in a rock mass influences the resistance of mining. However, these dependencies have not been presented, especially in relation to various methods of mining. An example is the analysis of the influence of travertine anisotropy on the efficiency of diamond line cutting (Ozcelik and Yilmazkaya, 2011). This study also contains an extensive review of works in the field of anisotropy of hard coal, diatomite, sandstone and other rocks. In one of the studies, the authors undertook to explain the effect of rock anisotropy on the drilling process by means of numerical analyses (Schormair et al., 2006). The study is only concerned with the analysis of results obtained for percussion drilling.

\section{Mechanical cutting of rocks}

The equipment that is most often used for mechanical cutting of rock raw materials includes cutting, planning or drilling machines. In this article, the focus has been placed on selected most popular machines. The recommendations presented in subsequent chapters also apply to the machines listed below (machine numbering is the same as in subsequent drawings)

1, 2. roadheaders (fig. 2 b),

3. longwall shearers (fig. 2a),

4. coal ploughs (fig. 2c),

5. longwall shearers with vertical axes of rotation of the cutting heads (fig. $2 \mathrm{~d}$ ),

6. shearers drilling in Auger Mining System (fig. 2e),

7. continuous miners and machines for Continuous Highwall Mining (fig. 2f).

These machines are to various degree used all over the world. Roadheaders are widely applied in hard coal mines, but also in salt mines, ore mines, and the construction branch. Cutting shearers and coal ploughs are basic, and the most common cutter-loaders in mechanized longwall systems used to mine hard coal deposits. Similarly, longwall shearers with vertical axes of rotation of cutterheads are applied in the mining of hard coal deposits. Drilling machines are used in underground mines with thin and steeply sloped deposits, whereas continuous miners, similarly to roadheaders, work in various mines, such as ore, hard coal, rock salt mines (Bołoz, 2018a), (Bołoz, 2018b).

Working elements of mining machines are the subject of numerous studies and investigations in the field of design (Bołoz and Castaneda, 2018), (Bołoz and Midor, 2018), (Kotwica, 2018), (Gospodarczyk et al., 2013), (Gospodarczyk et al., 2016) as well as the selection, wear and renovation of mining tools (Bołoz, 2019), (Bołoz and Midor, 2019), (Prokopenko et al., 2018), (Ťavodová et al., 2016), (Hasilová and Gajewski, 2019). The cutterheads that have been schematically presented in subsequent drawings are usually equipped with conical picks or flat picks. Flat, non-rotary picks (radial and forward attach picks) are typically applied as plough head tools. Conical or flat picks are the most frequently applied in cutterheads of various kinds of shearers. An 
exception is the shearer produced by Corum, which has been shown in the figure above. The most energyconsuming process carried out by these machines is the winning process, which "consumes" the most of machine power. Hence, a more precise estimate of power demand based on correctly determined and interpreted mechanical properties of unmined rock will result in a better selection of machines.

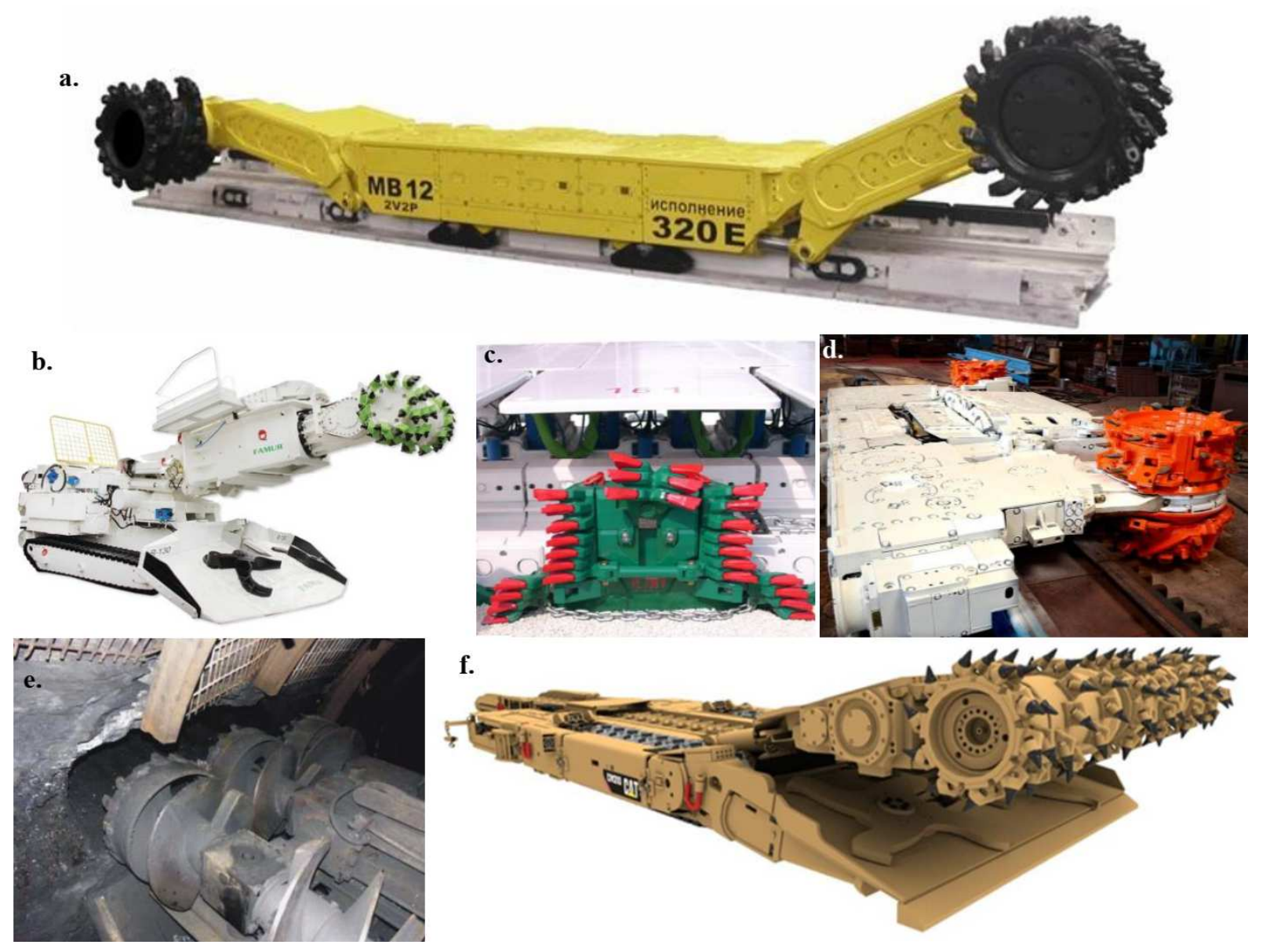

Fig. 2. Selected winning machines in underground mining: a. longwall shearer (MB12 320 E TMachinery a. s.), b. roadheader ( $R$-130 FAMUR S. A.), c. coal plough (PL 738V Ostroj a. s.), d. longwall shearer with vertical axes (KTB200 Corum Group), e. drilling shearer (VS-SEAL-625 z OKD Ostrava), f. continuous miner (CM210 CAT)

\section{Investigations into mechanical properties of rocks}

Physical and mechanical properties of rocks numerically describe their most important features. Physical parameters include absorbability as well as differently defined density and humidity. Among mechanical parameters, the following are listed: differently defined strength, internal friction angle, cohesion, Poisson ratio, mineability index, toughness index as well as abrasiveness and abrasibility. Parameters that are of huge importance for the mining process are mechanical properties. In practice, the most frequently determined is uniaxial compressive strength, but it is insufficient to select tools and estimate the resistance of mining. From the point of view of tools durability, an important parameter is rock abrasiveness (Mucha, 2019), which is a key issue in terms of pick replacement frequency, but it is not the subject of this article. The parameter which defines the resistance of unmined rock during the winning process is mineability. Uniaxial compressive strength is determined in accordance with standards concerning sample preparation (PN-G-04301) and strength determination (PN-G-04303), while rock mineability is defined by means of two values: cuttability index A and breakout angle $\psi$. According to the method developed by AGH University of Science and Technology, it is empirically determined by measuring the cutting force when making a straight cut of a specified depth, with a specified pick. The station for testing the planing process enables making a cut of a specified depth, width and length. During the cutting process, the values of signals from the system of sensors embedded in the holder with strain gauges are recorded, which allows for determining the value of the cutting, side and normal force. After making the cut, its real depth and width are measured. Knowing the cutting resistance, the depth of cutting and the values of relevant indexes, one can determine the cuttability, which is proportional to the force of cutting and inversely proportional to the depth of cutting (Krauze, 2000). 


\section{Anisotropy of mechanical rock properties on the basis of investigations}

Anisotropy of rocks has been demonstrated in numerous investigations and publications. Below have been presented the results of laboratory tests conducted by the author or with his participation. The research was aimed at determining the mechanical properties of unmined rock in order to select the best mining method, so it concerned typical rocks that are mined mechanically, such as hard coal, rock salt, copper ores.

Investigations into hard coal were based on samples provided from two different locations, from mines in Ordos, China. Tests were carried out in order to determine the uniaxial compressive strength and cuttability index (Fig. 3). The strength was determined for three perpendicular directions. The cuttability index was measured on three perpendicular planes in two perpendicular directions.
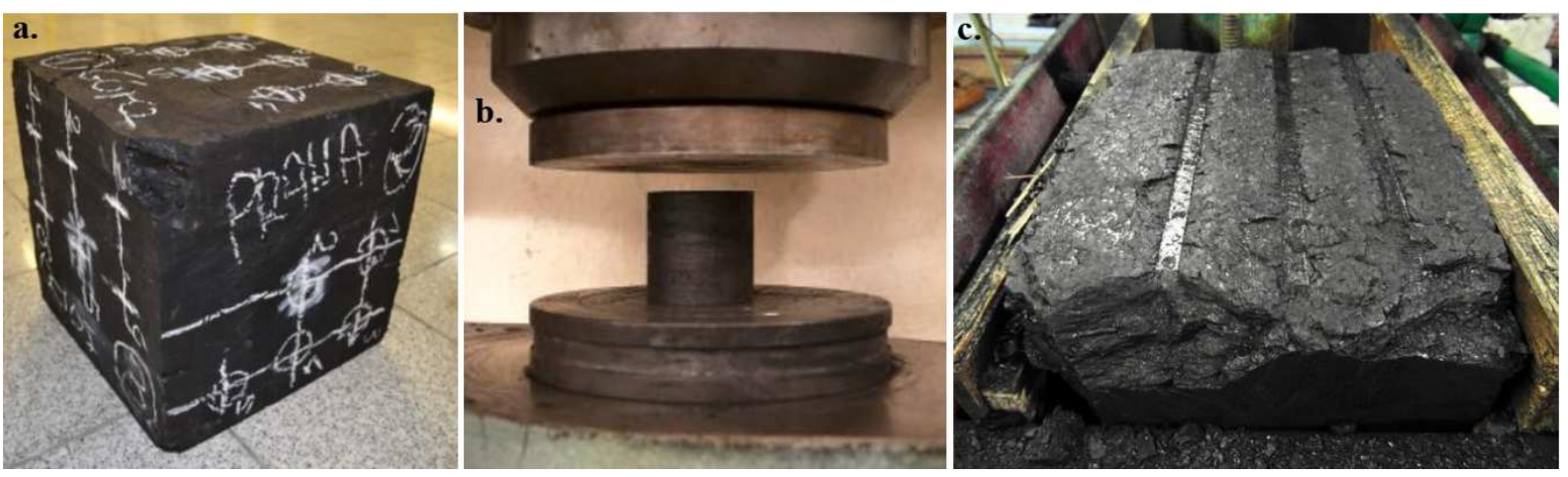

Fig. 3. The investigation into hard coal: a. provided sample b. before $R_{c}$ tests, c. after cuttability index tests

The results of tests for the coal from the first location have been given in Table 1. Differences between particular $R_{c}$ values for different cutting directions are very big. The strength in the up-down direction accounts for more than $300 \%$ of the value for the right-left direction. It is similar in the case of cuttability index. Index $A$ for the right longwall accounts for ca $175 \%$ of the index for the sidewall. A noticeable difference is also observed for two directions on one longwall. For example, the index on the right longwall in the up-down direction constitutes $150 \%$ of the value for the perpendicular direction, i.e., back sidewall. In consequence, the category of the tested coal mineability changes depending on the direction from well mineable to more than average mineable despite the fact that it concerns the same samples.

Tab. 1. Results of tests for the coal from the first location

\begin{tabular}{|c|c|c|c|c|c|c|c|}
\hline No. & Re direction & $\mathrm{Rc}[\mathrm{MPa}]$ & Longwall & Direction A & $A[N / c m]$ & $\psi\left[^{\circ}\right]$ & Category \\
\hline \multirow{2}{*}{1} & \multirow{2}{*}{ up-down } & \multirow{2}{*}{14} & \multirow{2}{*}{ sidewall } & up-down & 1137 & 44 & well mineable \\
\hline & & & & right-left & 1738 & 45 & average mineable \\
\hline \multirow{2}{*}{2} & \multirow{2}{*}{ right-left } & \multirow{2}{*}{5} & \multirow{2}{*}{ up } & back-sidewall & 1252 & 49 & average mineable \\
\hline & & & & right-left & 1557 & 47 & average mineable \\
\hline \multirow{2}{*}{3} & \multirow{2}{*}{ sidewall-back } & \multirow{2}{*}{9} & \multirow{2}{*}{ right } & up-down & 1982 & 57 & more than average mineable \\
\hline & & & & back-sidewall & 1347 & 47 & average mineable \\
\hline
\end{tabular}

Similarly, for the coal from the other location, the results have been presented in Table 2 . The strength in the up-down direction accounts for nearly $370 \%$ of the value for the right-left direction. The cuttability index $A$ is different depending on the longwall and direction. Index A on the right longwall in the back-sidewall direction accounts for more than $125 \%$ of the value for the perpendicular direction, i.e. up-down. As a result, the category of the tested coal mineability ranges from more than average to hard mineable.

Tab. 2. Results of tests for the coal from the second location

\begin{tabular}{|c|c|c|c|c|c|c|c|}
\hline No. & $\mathbf{R}_{\mathrm{c}}$ direction & $\mathbf{R}_{\mathrm{c}}[\mathrm{MPa}]$ & Longwall & Direction A & $A[N / c m]$ & $\psi\left[\left[^{\circ}\right]\right.$ & Category \\
\hline \multirow{2}{*}{1} & \multirow{2}{*}{ up-down } & \multirow{2}{*}{19} & \multirow{2}{*}{ sidewall } & up-down & 1975 & 62 & hard mineable \\
\hline & & & & right-left & 2367 & 57 & more than average mineable \\
\hline \multirow{2}{*}{2} & \multirow{2}{*}{ right-left } & \multirow{2}{*}{5} & \multirow{2}{*}{ up } & back-sidewall & 2113 & 59 & more than average mineable \\
\hline & & & & right-left & 2292 & 57 & more than average mineable \\
\hline \multirow{2}{*}{3} & \multirow{2}{*}{ sidewall-back } & \multirow{2}{*}{6} & \multirow{2}{*}{ right } & up-down & 1889 & 59 & more than average mineable \\
\hline & & & & back-sidewall & 2395 & 58 & more than average mineable \\
\hline
\end{tabular}


One of the projects involved conducting comprehensive investigations into copper ores in the form of dolomites, sandstones and shales. An appropriate amount of rock was taken from the mine, and more than one hundred samples were prepared for strength and cuttability tests (Fig. 4, Fig. 5). Uniaxial compressive strength and cuttability in three directions were tested. Below have been presented maximum observed values determined on the basis of samples taken from one solid for each of the rocks (Tab. 3, Tab. 4, Tab. 5).
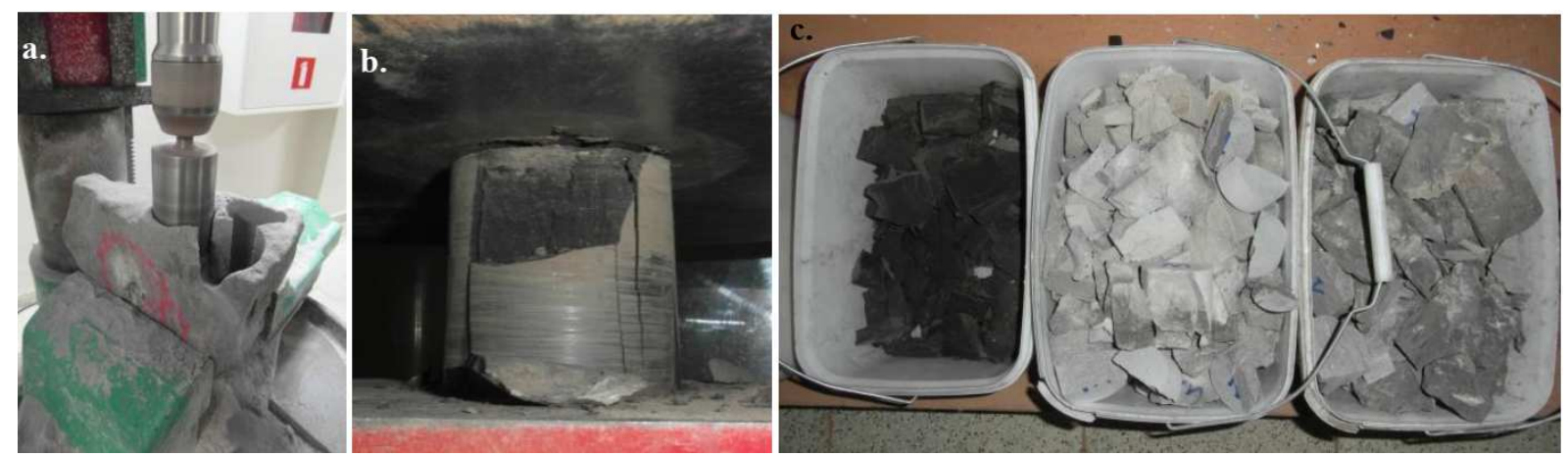

Fig. 4. Investigations into $R_{c}$ of copper ores: a. sample preparation, $b$. shale during $R_{c}$ testing, $c$. a scrap of shale, sandstone and dolomite after tests
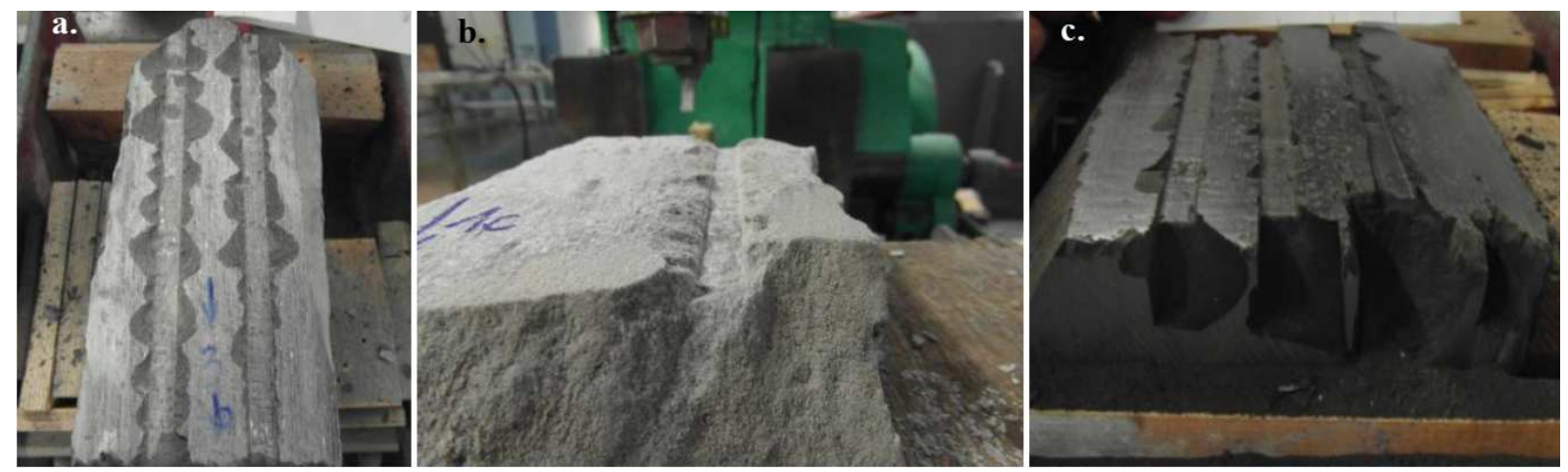

Fig. 5. Copper ores cuttability tests: $a$. dolomite, $b$. sandstone, $c$. shale

The results of compressive strength tests for sandstone indicate high differentiation of values for all three directions. The biggest - 4, 5-fold differences can be observed between the up-down and back-sidewall directions. The value of one of the remaining combinations of directions is twice higher than that of the other combination. Similarly, the cuttability index for the back-sidewall direction is twice lower than the value for the remaining directions. Due to high values irrespective of the direction, this sandstone has been classified as particularly hard mineable. It should be noted, however, that the applied classification does not have a separate category for values higher than those described with the term of "particularly hard mineable", although they can be four times higher.

Tab. 3. Results of tests for sandstone

\begin{tabular}{|c|c|c|c|c|c|c|}
\hline No. & Rc direction & Rc $[\mathbf{M P a}]$ & Direction A & $\mathbf{A}[\mathbf{N} / \mathbf{c m}]$ & $\boldsymbol{\Psi}\left[^{\circ}\right]$ & Category \\
\hline 1 & up-down & 16 & up-down & 22886 & 39 & particularly hard mineable \\
\hline 2 & right-left & 72 & back-sidewall & 11716 & 65 & particularly hard mineable \\
\hline 3 & sidewall-back & 37 & up-down & 20610 & 49 & particularly hard mineable \\
\hline
\end{tabular}

For dolomite strength results, the relative differences are not so big. The largest difference between the sidewall-back and up-down direction is slightly more than $40 \%$, which, however, with high strength values reaches almost $40 \mathrm{MPa}$. On the other hand, there is a significant difference in the cuttability index, the values of which are twice higher. Hence, there is a difference in the mineability category between the up-down and the remaining directions. 
Tab. 4. Results of tests for dolomite

\begin{tabular}{|c|c|c|c|c|c|c|}
\hline No. & $\mathbf{R}_{\mathbf{c}}$ direction & $\mathbf{R}_{\mathbf{c}}[\mathbf{M P a}]$ & Direction $\mathbf{A}$ & $\mathbf{A}[\mathbf{N} / \mathbf{c m}]$ & $\boldsymbol{\Psi}\left[^{\circ}\right]$ & Category \\
\hline 1 & up-down & 89 & up-down & 2559 & 71 & hard mineable \\
\hline 2 & right-left & 104 & back-sidewall & 5252 & 61 & particularly hard mineable \\
\hline 3 & sidewall-back & 127 & up-down & 5303 & 75 & particularly hard mineable \\
\hline
\end{tabular}

Shale tests revealed differences in uniaxial compressive strength, the level of which was more than twice higher for one of the values. A considerably lower strength in the sidewall-back direction and the characteristic shale structure caused that the sample was destroyed during cuttability tests in the up-down direction. The results of the cuttability index for the remaining directions differ by nearly $35 \%$. An interesting finding is more than a triple difference in the value of breakout angle $\psi$. This, however, is a typical characteristic of shale.

Tab. 5. Results of tests for shale

\begin{tabular}{|c|c|c|c|c|c|c|c|}
\hline No. & $\mathbf{R}_{\mathbf{c}}$ direction & $\mathbf{R}_{\mathbf{c}}[\mathbf{M P a}]$ & Direction $\mathbf{A}$ & $\mathbf{A}[\mathbf{N} / \mathbf{c m}]$ & $\boldsymbol{\Psi}\left[^{\circ}\right]$ & \multicolumn{5}{|c|}{ Category } \\
\hline 1 & up-down & 63 & \multicolumn{5}{|c|}{ sample was destroyed } \\
\hline 2 & right-left & 61 & back-sidewall & 6097 & 22 & particularly hard mineable \\
\hline 3 & sidewall-back & 27 & up-down & 4549 & 71 & particularly hard mineable \\
\hline
\end{tabular}

In recent years, single investigations have often been carried out to determine the uniaxial compressive strength of various types of rock in three directions. It should be emphasized that depending on the type and homogeneity of the rock, the results even for one direction may vary several times. For example, dolomite was characterized by significant differences; in the case of single samples tested in one direction, more than a threefold difference in results was observed (158 MPa and $46 \mathrm{MPa})$. However, individual, much lower than other values are not important for the estimation of energy consumption of the process and for the choice of the mining method. One should be guided by the maximum values. Differences in the results of tests for various samples of dolomite and sandstone reached up to approximately $50 \%$, depending on the compression direction, for example, $113 \mathrm{MPa}$ and $77 \mathrm{MPa}$ for two perpendicular directions of compression.

Rock salt is an example of a mineral that, from the point of view of mechanical cutting, has several interesting properties (Mansouri and Ajalloeian 2018), (He et al., 2019). Salt is not very abrasive, which means that it causes the wear of tools only to a small extent. Salt is characterized by quite high cutting resistance and frequently - by high cutting indexes. Samples of rock salt from the Polish mines were subjected to tests (Fig. 6).
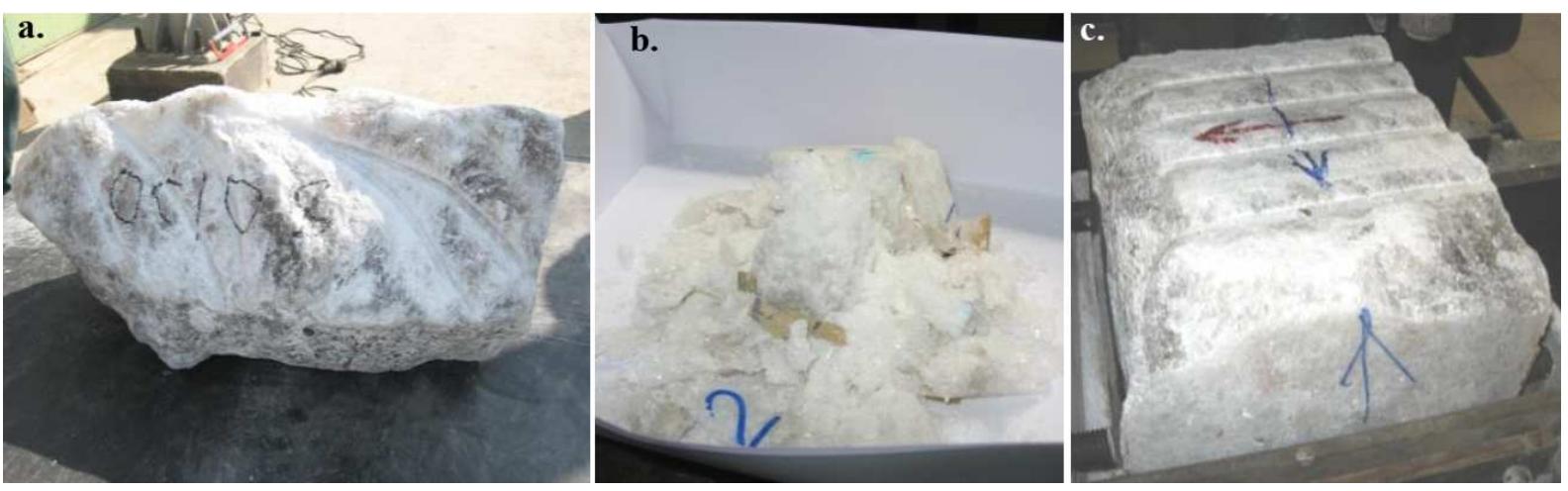

Fig. 6. Rock salt tests: a. provided sample b. after $R_{c}$ tests, $c$. after cuttability index tests

Investigations into the mechanical properties of salts in three directions have revealed that the obtained values of uniaxial compression strength depend on the direction to a lesser extent. The value of uniaxial compressive strength determined for perpendicular directions was $35 \mathrm{MPa}, 33 \mathrm{MPa}$ and $34 \mathrm{MPa}$, respectively, which means that the differences do not exceed 6\%. In some extreme cases, the differences for individual samples reached ca $17 \%$. Due to the specificity of the mining process and the scope of the order, the cuttability tests were carried out only for two perpendicular directions. The average cuttability index A was $5083 \mathrm{~N} / \mathrm{cm}$ and $5860 \mathrm{~N} / \mathrm{cm}$, respectively. The difference reaches over 15\%, with maximum differences of nearly $35 \%$. 


\section{The direction of mechanical properties determination with respect to the mining method}

In order to determine the mechanical properties of unmined rock, its cuttability index, breakout angle, toughness or uniaxial compressive strength are tested. Tests are usually performed for samples taken from the excavated workings. Taking a sample for tests enables determining its properties in any direction in laboratory conditions. It should be noted that toughness is an energy indicator and does not depend on the direction. A sample can be taken from working to be mined by means of various previously mentioned machines. For the diagram shown in Fig. 7, the sample can be taken from excavations marked A, B or C. For a popular longwall system, sample P3 can be taken from the longwall (excavation C), sample P2 from the top road (excavation B) or sample P1 from the bottom road (excavation A). Typically, the use of roadheader $(1,2)$ was considered for roadway excavations and the use of longwall shearer (3) and coal plough (4) for the longwall. At the same time, it was assumed that, apart from classic longwall shearers, also cutting shearers with vertical axes of rotation of the heads could be used (5). The diagram also includes a boring machine in the Auger Mining system (6) and a cutterhead for the Continuous Highwall Mining system (7). The last two systems are not used in typical longwall excavations. However, in this situation, samples marked as P1 and P2 can be taken from previously made holes or headings described as excavations $\mathrm{A}$ and $\mathrm{B}$, so the cutting direction system remains the same. The situation is similar for the room and pillar mining system, where the continuous miner is used. The interpretation for such a shearer is identical as for the cutting head (7).

The presented layout of sampling locations in specific excavations can also be generalized for other mining excavations and machines used, for example for borer miners, such as Ural-360, Marietta, Xcel Miners 4-Rotor or for cutting machines. Then, the direction of cutting and the corresponding direction of determining the mechanical properties of the sample should be analyzed using the method presented below.

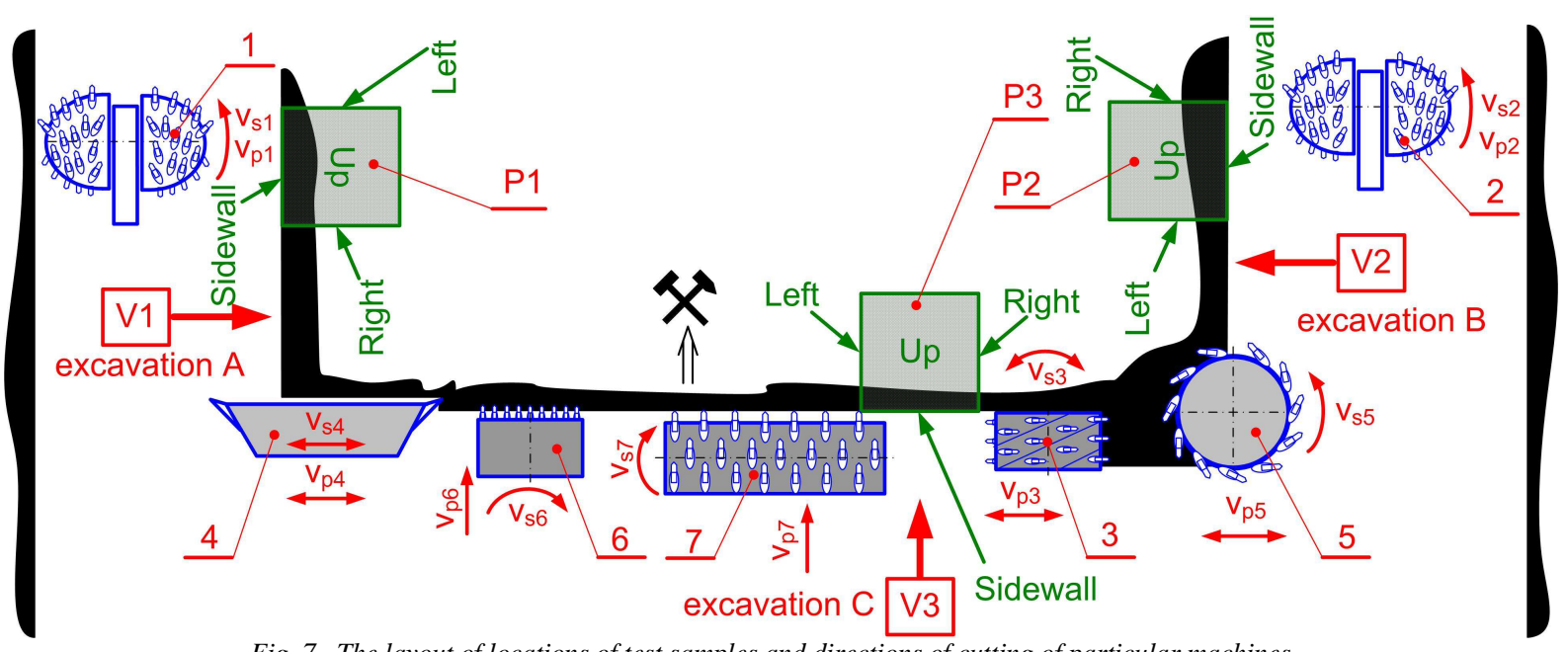

Fig. 7. The layout of locations of test samples and directions of cutting of particular machines

Markings in Fig. 7:

$\mathrm{P} 1$ - sample located in excavation A,

$\mathrm{P} 2$ - sample located in excavation $\mathrm{B}$,

$\mathrm{P} 3$ - sample located in excavation $\mathrm{C}$,

1 - roadheader in excavation $\mathrm{A}$,

2 - roadheader in excavation $\mathrm{B}$,

3 - classic longwall shearer,

4 - coal plough,

5 - longwall shearer with vertical axes of cutterheads,

6 - tunnel boring machine in Auger Mining System (AM),

7 - shearer in Continuous Highwall Mining System (CMH),

$\mathrm{v}_{\mathrm{p}}$-vector of cutting head travelling speed for each of the machines (1-7),

$\mathrm{v}_{\mathrm{s}}$ - vector of the cutterhead cutting speed for each of the machines (1-7),

$\mathrm{V} 1$ - view of unmined rock in excavation $\mathrm{A}$,

$\mathrm{V} 2$ - view of unmined rock in excavation $\mathrm{B}$,

$\mathrm{V} 3$ - view of unmined rock in excavation $\mathrm{C}$.

The place of cutting and the type of cutting machine determine the cutting direction and, in consequence, the direction in which mechanical properties of the unmined rock should be determined. Therefore, diagrams have been prepared for all excavations $(\mathrm{A}, \mathrm{B}, \mathrm{C})$ from which the sample may come (P1, P2, P3) so as to assign 
the direction of determining the mechanical properties of the sample taken to the type of mining machine used. The diagrams present the sample in three projections as well as the cutting heads. The cutting heads were correlated with a specific view of the sample. The drawings were made so as to enable an analysis of the cutting direction and the direction in which the mechanical properties of the sample should be determined. Three cases were analyzed as follows:

- $\quad$ sample P1 - a sample taken from excavation A - fig. 8,

- sample P2 - a sample taken from excavation B -

- fig. 9,

- $\quad$ sample P3 - a sample taken from excavation C - fig. 10.

Front view (V1)
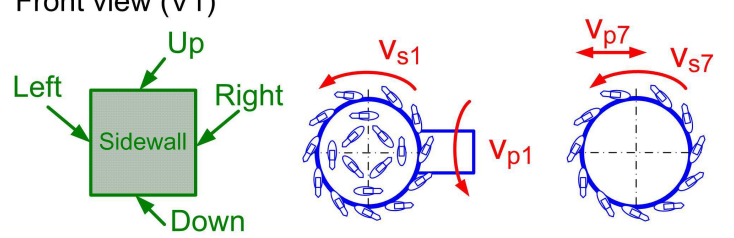

Cross section
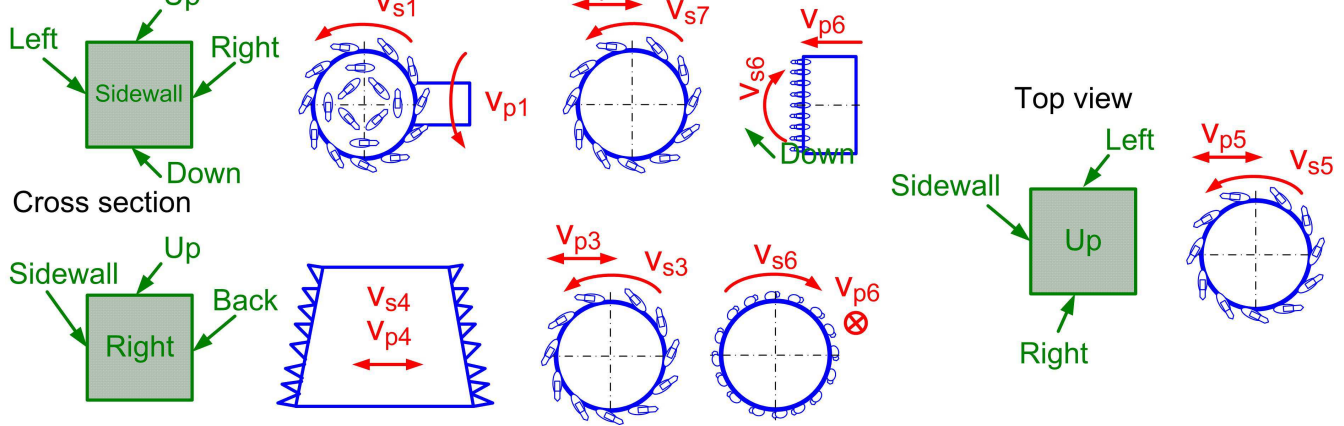

Fig. 8. Cutting directions for sample P1 taken from excavation A

Front view (V2)
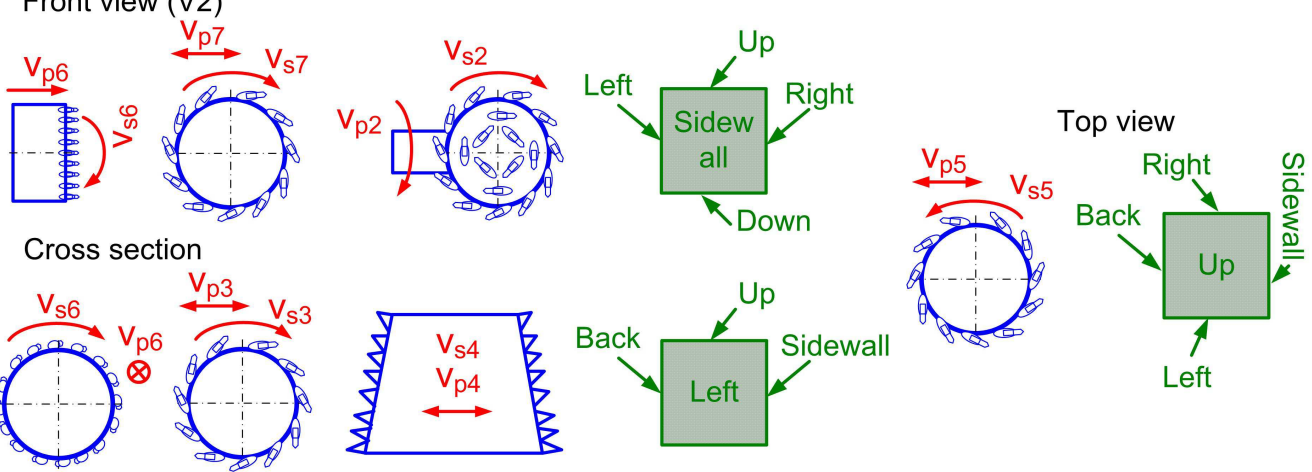

Fig. 9. Cutting directions for sample $P 2$ taken from excavation $B$

In each of the presented situations, the mining method depends on the direction in which the mechanical properties of the sample should be determined. The direction that most strongly influences the cutting resistance was determined for the analyzed cutting heads. The direction is understood as the direction in which the mechanical properties of the sample were determined. Uniaxial compressive strength can be determined for the sample in three perpendicular directions. Cuttability tests can also be carried out in three perpendicular directions on six available sample surfaces. The adopted names of sample surfaces were marked symbolically: up (U), down (D), right (R), left (L), sidewall (S), back (B), so there are three directions for uniaxial compressive strength: U-D, R-L, S-B. Cuttability tests can be done in two perpendicular directions on each of the longwalls, for example on the sidewall surface in U-D and R-L direction. In addition, cuttability tests can be performed for two orientations in each direction, for example, U-D and D-U. Until present, the impact of cutting orientation on the obtained results of cuttability tests has not been comprehensively studied. Based on the research results, it can be concluded that orientation does have an impact, especially if the surface prepared for cutting is not perpendicular or parallel to the cleavage plane. Recommended planes, directions and orientations have been given below. If the mining method is known, the rock properties should be determined in accordance with the provided recommendations. In the case of coal ploughs and longwall shearers, the direction of the cutting speed vector changes with a change in the direction of machine movement in the longwall. 
Front view (V3)
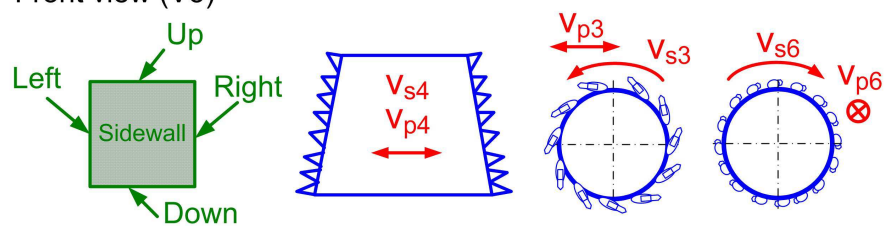

Cross section
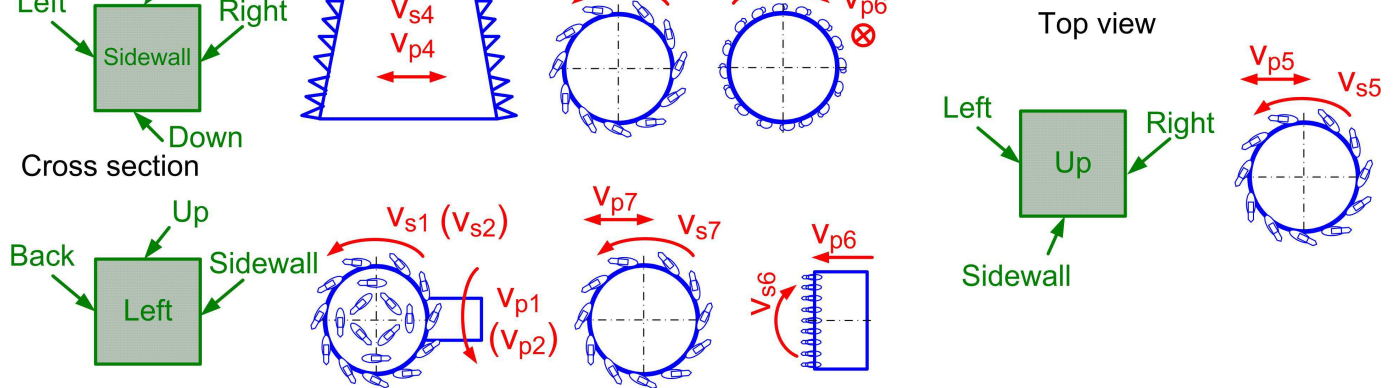

Sidewall

Fig. 10. Cutting directions for sample P3 taken from excavation $C$

In the case of sample P1 taken from excavation A (Fig. 8), the following dependencies are observed:

- $\quad$ mining with roadheader (1) and CHM (7):

o uniaxial compressive strength in U-D direction,

o cuttability on R surface, U-D orientation,

- $\quad$ mining with longwall shearer (3):

o uniaxial compressive strength in U-D direction,

o cuttability on B or S surface, U-D or D-U orientation,

- $\quad$ mining with plough head (4):

o uniaxial compressive strength in S-B direction,

o cuttability on R surface, S-B and B-S orientation,

- $\quad$ mining with longwall shearer with vertical axes (5):

o uniaxial compressive strength in R-L direction,

o cuttability on B or S surface, L-R orientation

- $\quad$ mining with a boring head (6):

o uniaxial compressive strength in R-L direction,

$\mathrm{O}$ drillability in R-L drilling direction.

In the case of sample P2 taken from excavation B (Fig. 9), the following dependencies are observed:

- $\quad$ mining with roadheader (2) and CHM (7):

o uniaxial compressive strength in U-D direction,

○ cuttability on L surface, U-D orientation,

- $\quad$ mining with longwall shearer (3):

○ uniaxial compressive strength in U-D direction,

o cuttability on B or S surface, U-D and, possibly, D-U orientation,

- $\quad$ mining with plough head (4):

$\circ$ uniaxial compressive strength in S-B direction,

o cuttability on surface L, S-B and B-S orientation,

- $\quad$ mining with longwall shearer with vertical axes (5):

o uniaxial compressive strength in R-L direction,

o cuttability on B or S surface, R-L orientation.

- $\quad$ mining with drilling head (6):

o uniaxial compressive strength in R-L direction,

$\circ$ drillability in L-R drilling direction.

In the case of sample P3, taken from excavation C (Fig. 10), the following dependencies can be observed

- $\quad$ mining with roadheader $(1,2)$ and CHM (7):

o uniaxial compressive strength in U-D direction,

o cuttability on S surface, U-D orientation,

- $\quad$ mining with longwall shearer (3):

○ uniaxial compressive strength in U-D direction,

O cuttability on R or L surface, U-D and, possibly, D-U orientation,

- mining with plough head (4):

o uniaxial compressive strength in R-L direction,

o cuttability on S surface, R-L and L-R orientation,

- $\quad$ mining with longwall shearer with vertical axes (5): 
$\circ$ uniaxial compressive strength in S-B direction,

o cuttability on R or L surface, B-S orientation,

- $\quad$ mining with drilling head (6):

o uniaxial compressive strength in S-B direction,

$\circ$ drillability in S-B drilling direction.

The two-way classic longwall shearer is equipped with two cutting heads, which cut in opposite directions. The front head usually cuts downward, while the back one - upward. The front cutterhead cuts with its entire diameter, hence the most important thing is to determine the U-D cuttability, whereas the back head cuts the remained coal towards the free surface, hence the mining resistance is lower, and there is no need to determine the D-U cuttability.

Longwall shearers with vertical axes are equipped with two cutting heads, which cut in the same direction, i.e. towards the free surface, regardless of the direction of the shearer's movement. The cutting direction in the coal plough is identical with the direction of the head's movement. However, in the case of other machines $(1,2$, $6,7)$ there is no change in the direction of cutting.

In the case of drilling with a head (6) equipped with conical picks, the picks cut the unmined rock in a plane perpendicular to the direction of drilling. Each pick is in contact with unmined rock at all times. This type of cutting necessitates the determination of the value of uniaxial compressive strength in three directions and the value of cuttability on four planes. To simplify the determination of unmined rock properties for drilling, it is recommended that drillability should be determined in accordance with the drilling direction and uniaxial compressive strength in the same direction.

Samples P1 and P2 can also be taken from the face of excavation A and B; in such a case, the analysis in question also applies. On the other hand, samples P1 and P2 can be taken from the sidewall of the gallery, which is opposite to the one indicated in the drawing. In this case, appropriate directions should be taken into account in the analysis, according to the presented methodology. Sample P3 can be taken from the drift face; in such a case, the interpretation of directions will remain unchanged.

\section{Summary}

The presented test results do not allow for approaching the problem in a comprehensive way but provide sufficient evidence pointing to the existence of significant discrepancies, depending on the direction of determining the mechanical properties of rocks. In some cases, the differences reach 500\%. It should be emphasized that there is no need to perform tests in three directions. However, it is crucial to analyze all the potential mining methods and take them into consideration when determining the mechanical properties of rocks. Knowing the sample orientation in the deposit and using the presented methodology, it is possible to specify the way of determining mechanical properties so that the results are adjusted to the planned method of mining to the largest extent possible. In the event various techniques or machines are considered, testing may be required in more than one direction.

If the mining technique is well known, for example, if it is a very common method of mining with a longwall shearer, the only problem comes down to choosing the direction of determining the mechanical properties, as shown above. So obtained results will allow for a more accurate estimate of the cutterheads' power demand.

The investigations, the results of which are quoted in the article, have revealed the need for further research so as to determine unambiguous dependences, especially with respect to the effect of the cutting orientation during cuttability tests on the obtained test results. The tests conducted in different directions and in perpendicular orientations give only a general view on this issue, indicating differences in the results.

The most important conclusion and recommendation is to carefully select the direction of determining rock properties depending on the method planned. To facilitate the interpretation of results and sproperly choose this direction, the methodology presented in the article should be applied.

The literature review has revealed numerous reports of the rock anisotropy problem. Researchers draw attention to the impact of properties determination direction in relation to the deposition or stratification of rock samples on the obtained results. However, until the present, this issue has not been described comprehensively in terms of mechanical mining. The problem presented in the article, together with recommendations regarding the choice of direction for determining rock properties and their interpretation in the case of selecting the method of exploitation is the first such study. 


\section{References}

Agustawijaya, D. S. (2007). The Uniaxial Compressive Strength of Soft Rock. Civil Engineering Dimension. 9(1), pp. 9-14

Biały, W. (2013) New devices used in determining and assessing mechanical characteristics of coal. $13^{\text {th }}$ SGEM GeoConference on Science and Technologies in Geology, Exploration and Mining, SGEM2013 Conference Proceedings, June 16-22, 2013, Vol. 1, BUŁGARIA ISBN 978-954-91818-7-6/ISSN 13142704. pp. 547-554.

Biały, W. (2014). Coal cutting force measurement systems - (CCFM). $14^{\text {th }}$ SGEM GeoConference on Science and Technologies In Geology. Exploration and Mining. SGEM2014 Conference Proceedings, Vol. III, pp. 91-98.

Biały, W. and Fries, J. (2019). Computer Systems Supporting the Management of Machines/Equipment in Hard

Coal Mines. Case Study. Management Systems in Production Engineering, Volume 27 issue 3/2019. pp.

138-143. ISSN 2299_0461. DOI 10.1515/mspe-2019-0022

Bołoz, Ł. (2018). Longwall shearers for exploiting thin coal seams as well as thin and highly inclined coal seams, "Mining - Informatics, Automation and Electrical Engineering", 2(534), pp. 59-65.

Bołoz, Ł. (2018). Mining of thin coal seams using surface-underground methods, "Mining - Informatics, Automation and Electrical Engineering", 3(535), pp. 59-73.

Bołoz, Ł. (2019). Directions for increasing conical picks' durability, In: New trends in production engineering, Sciendo, 2(1), pp. 277-285.

Bołoz, Ł., Krauze, K. and Kubin, T. (2018). Mechanization of longwall extraction of hard and abrasive rocks. Multidisciplinary Aspects of Production Engineering. Sciendo, 1(1), pp. 331-337.

Bołoz, Ł. and Leonel, F. Castañeda, (2018). Computer-aided support for the rapid creation of parametric models of milling units for longwall shearers. Management Systems in Production Engineering, 26(4), pp. 193199.

Bołoz, Ł. and Midor, K. (2018). Process innovations in mining industry and effects of their implementation presented on example of longwall milling heads. Acta Montanistica Slovaca, 23(3), pp. 282-292.

Bołoz, $Ł$. and Midor, K. (2019). The procedure of choosing an optimal offer for a conical pick as an element of realizing the sustainable development concept in mining enterprises. Acta Montanistica Slovaca, 24(2), pp. 140-150.

Dinc, O., Sonmez H., Tunusluoglu C. and Kasapoglu K.E. (2011). A new general empirical approach for the prediction of rock mass strengths of soft to hard rock masses, International Journal of Rock Mechanics and Mining Sciences, 48, pp. 650-665.

Gospodarczyk, P., Kotwica, K. and Stopka, G. (2013). A new generation mining head with disc tool of complex trajectory, Archives of Mining Sciences, 58(4), pp. 985-1006.

Gospodarczyk, P., Kotwica, K., Mendyka, P. and Stopka, G. (2016). Innovative roadheader mining head with asymmetrical disc tools, Exploration and mining, mineral processing. International Multidisciplinary Scientific GeoConference SGEM, 2, pp. 489-496.

Hasilová, K. and Gajewski, J. (2019). The use of kernel density estimates for classification of ripping tool wear, Tunnelling and Underground Space Technology, 88, pp. 29-34.

He M., Li N., Zhu C., Chen Y. and Wua H. (2019). Experimental investigation and damage modeling of salt rock subjected to fatigue loading, International Journal of Rock Mechanics and Mining Sciences, 114, pp. 17-23.

Hoek, E. and Brown, E.T. (1980). Empirical Strength Criterion for Rock Masses. Journal of Geotechnical and Geoenvironmental Engineering, 106, pp. 1013-1035.

Kotwica, K. (2018). Atypical and innovative tool, holder and mining head designed for roadheaders used to tunnel and gallery drilling in hard rock. Tunnelling and Underground Space Technology, 82, pp. 493-503.

Krauze, K. (2000). Urabianie skał kombajnami ścianowymi. Wydawnictwo naukowe „Śląsk”, Katowice,

Majcherczyk, T. and Niedbalski, Z. (2004). Wpływ nachylenia otworów badawczych na zmianę parametrów wytrzymałościowych skał, XXVII Zimowa szkoła mechaniki górotworu, Kraków, pp. 898-907.

Małkowski, P. (2015). The impact of the physical model selection and rock mass stratification on the results of numerical calculations of the state of rock mass deformation around the roadways, Tunnelling and Underground Space Technology, 50, pp. 365-375.

Mansouri, H. and Ajalloeian, R. (2018). Mechanical behavior of salt rock under uniaxial compression and creep tests, International Journal of Rock Mechanics and Mining Sciences, 110, pp. 19-27.

Mucha, K. (2019). The new method for assessing rock abrasivity in terms of wear od conical picks. In: New Trends in Production Engineering, Sciendo, 2(1), pp. 186-194.

Muller, L. and Pacher, F. (1965). Modellversuche zur Klarung der Bruchgefahr geklufteter Medien, Felsmech. u. Ing. Geol., Suppl. II, pp. 7-24. 
Nasseria, M.H.B., Raob K.S. and Ramamurthyb T. (2003). Anisotropic strength and deformational behavior of Himalayan schists, International Journal of Rock Mechanics \& Mining Sciences, 48, pp. 626-636.

Ozcelik, Y. and Yilmazkaya E. (2011). The effect of the rock anisotropy on the efficiency of diamond wire cutting machines, International Journal of Rock Mechanics \& Mining Sciences, 40, pp 3-23.

Özbek, A., Gül, M., Karacan, E. and Alca, Ö. (2018). Anisotropy effect on strengths of metamorphic rocks, Journal of Rock Mechanics and Geotechnical Engineering, 10, pp. 165-175.

Prokopenko, S. A., Vorobiev, A. V., Lyudmila, A. and Janocko, J. (2018). Waste Cutters Utilization in Underground Coal Mining, Acta Montanistica Slovaca, 23(1), pp. 81-89.

Schormair, N., Thuro, K. and Plinninger, R. (2006). The influence of anisotropy on hard rock drilling and cutting, The Geological Society of London, IAEG, Paper 491, pp. 1-11.

Shuxin, W. (1992). Fundamental studies of the deformability and strength of jointed rock masses at threedimensional level, dissertation, The University of Arizona (http://hdl.handle.net/10150/185923).

Ťavodová, M., Kalincová, D., Hnilicová, M. and Hnilica R. (2016). The influence of heat treatment on tool properties mulcher, Manufacturing technology, 16(5), pp. 1169-1173. 